\title{
Persistent Pulmonary Hypertension of the Newborn: Recent Advances in the Management
}

\author{
Amit Agrawala, c, Rashmi Agrawal ${ }^{\mathrm{b}}$
}

\begin{abstract}
Persistent pulmonary hypertension of the newborn (PPHN) is a medical emergency in the neonatal period, which occurs due to failure of normal postnatal transition of fetal circulation. Despite availability of numerous treatment modalities, associated mortality and morbidity remain high. Therefore, awareness of predisposing conditions, and early diagnosis and management may help improving outcome in PPHN. To provide an overview of anatomic and functional anomalies of PPHN, and available treatment options with special focus on recent advances in the diagnosis and management of this potentially lethal illness. MEDLINE, EMBASE, The Cochrane Library, and Google Scholar databases were searched (inception until Nov-2012) using terms "persistent pulmonary hypertension of newborn", "hypoxemic respiratory failure", "nitric oxide", "sildenafil", "milrinone" and "prostacyclin" without any language restriction. www.clinicaltrials.gov website was searched for relevant ongoing trials. Additionally, manual review of article bibliographies was done for potentially relevant studies. Strategies for the management of PPHN are undergoing metamorphosis. Gentle ventilation and high-frequency ventilation have replaced prior hyperventilation strategy. Currently, iNO is the only FDA-approved selective pulmonary vasodilator for infants with hypoxemic respiratory failure/PPHN; however, it has poor/no response in upto $30 \%$ cases. Recent studies have provided evidences for the use of other therapeutic agents such as PDE-inhibitors, magnesium sulphate and prostacyclin analogues. Finally, recent laboratory studies have demonstrated the role of oxidant stress as well as potential use of free radical scavengers for example, superoxide dismutase and catalase in the management of PPHN. Assisted ventilation and pharmacologic manipulation are the mainstays of treatment of PPHN. Lim-
\end{abstract}

Manuscript accepted for publication March 13, 2013

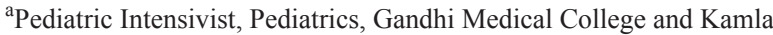
Nehru Hospital, Bhopal, MP, India

${ }^{\mathrm{b}}$ Consultant Gynecologist, Devmata Hospital, Bhopal, MP, India

${ }^{\mathrm{c}}$ Corresponding author: Amit Agrawal, 28, Ravidas Nagar, Near Nizamuddin Colony, Indrapuri, Bhopal, MP, 462021, India.

Email: agrawaldramit@yahoo.co.in

doi: http://dx.doi.org/10.4021/ijcp79w ited availability of the gold standard treatment option namely iNO, especially in resource-limited countries, leads to increasing use of alternative therapeutic options such as PDE-inhibitors (sildenafil and milrinone). However, as any single therapy can not be labelled as a magic bullet for PPHN, further clinical trials are required to demonstrate the efficacy and safety of available therapeutic options as well as to develop newer strategies targeted to the underlying pathophysiology.

Keywords: Persistent pulmonary hypertension; Newborn; Nitric oxide; Phosphodiesterase inhibitors; Sildenafil

\section{Introduction}

Persistence of pulmonary hypertension in neonates was described initially by Gersony and colleagues in 1969 as persistent fetal circulation [1]. Persistent pulmonary hypertension of the newborn (PPHN) can be defined as a failure of normal fall in pulmonary vascular resistance (PVR) at or shortly after birth, leading to shunting of unoxygenated blood into the systemic circulation across foramen ovale or ductus arteriosus [2]. Severity of PPHN can vary from mild, transient respiratory distress to severe hypoxemia and cardio-respiratory instability requiring intensive care support.

PPHN may be primary or secondary to meconium aspiration syndrome (MAS), hyaline membrane disease (HMD), sepsis, pneumonia, congenital diaphragmatic hernia (CDH), and congenital heart diseases (CHD). Incidence of PPHN is approximately 0.4-6.8/1,000 live births with estimated mortality of $10-20 \%$ and high risk of neurodevelopmental delay and other morbidities among survivors [3]. PPHN primarily affects full-term and near-term neonates, with MAS being the most common underlying cause followed by primary PPHN. However, as the incidence of MAS is going down coinciding with decreasing post-term deliveries and simultaneously increasing preterm deliveries, respiratory distress syndrome (RDS) in preterm neonates is becoming a significant contributory cause [4].

Currently, inhaled nitric oxide (iNO) is regarded as the gold standard of therapy for PPHN but upto $30 \%$ cases failed to show sustained response $[5,6]$. Recent advances have 


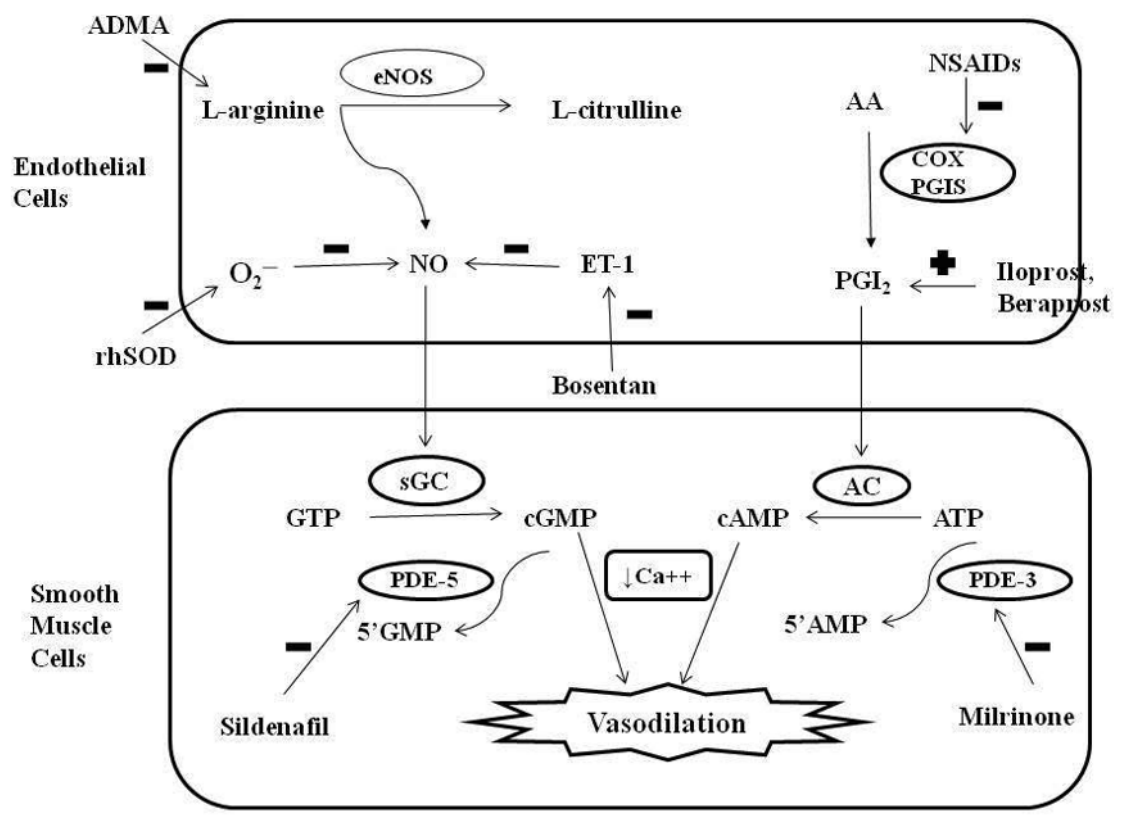

Figure 1. Role of nitric oxide $(\mathrm{NO})$ and prostacyclin $\left(\mathrm{PGI}_{2}\right)$ signaling pathways in the regulation of pulmonary vascular tone and mechanism of action of different pharmacologic agents. Endothelial NO synthase (eNOS) enzyme stimulates the synthesis of $\mathrm{NO}$ by stimulating the conversion of L-arginine to L-citrulline. NO increases intracellular cyclic guanosine monophosphate (cGMP) levels by stimulating soluble guanylate cyclase (sGC) enzyme. $\mathrm{PGI}_{2}$ is an arachidonic acid (AA) metabolite formed by cyclooxygenase (COX) and prostacyclin synthase (PGIS) enzymes in the vascular endothelium. $\mathrm{PGI}_{2}$ stimulates adenylate cyclase in vascular smooth muscle cells, which increases intracellular cyclic adenosine monophosphate (cAMP) levels. Both cGMP and cAMP mediate smooth muscle relaxation by decreasing free cytosolic calcium levels. These cyclic nucleotides are degraded by type 5 and type 3 phosphodiesterase (PDE) respectively thus limiting the duration of vasodilation. Sildenafil and milrinone inhibits PDE-5 and PDE-3 respectively and enhance pulmonary vasodilation. NO levels are decreased by endogenous $\mathrm{NO}$ antagonist asymmetric dimethyl arginine (ADMA), superoxide $\left(\mathrm{O}_{2}^{-}\right)$, and endothelin (ET-1). Exogenous NO administration, endothelin receptor antagonist (bosentan) and rhSOD (recombinant human superoxide dismutase) treatment may promote vasodilation in PPHN by increasing NO levels. Antenatal exposure to non-steroidal antiinflammatory drugs (NSAIDs) may cause PPHN by interfering with prostacyclin pathway through inhibition of COX. Prostacyclin analogues $\left(\mathrm{PGI}_{2}\right.$, beraprost sodium, iloprost) may help in PPHN by promoting vasodilation mediated via stimulation of adenylate cyclase. GTP: guanosine triphosphate; ATP: adenosine triphosphate.

expanded the therapeutics options available for PPHN, but optimal approach is still controversial. In this article, anatomic and functional anomalies of PPHN, latest advances in the diagnosis and treatment as well as future perspectives of the management of this potentially lethal illness will be discussed.

\section{Normal Pulmonary Vascular Transition}

Due to high PVR, fetal lung receives only $5-15 \%$ of the cardiac output, remainder shunting to systemic circulation [2]. Shortly after birth, rapid cardiopulmonary transition takes place and lungs take over the gas exchange function. In this process, PVR decreases dramatically with resultant fall in pulmonary arterial pressure (PAP) and increase in pulmonary blood flow [2]. Various factors like expansion of lungs, shear stress, increase in $\mathrm{PaO}_{2}$ and $\mathrm{pH}$, and decrease in $\mathrm{PaCO}_{2}$ help decreasing PVR by stimulating the release of NO, prostacyclin $\left(\mathrm{PGI}_{2}\right)$, bradykinin, and activating $\mathrm{K}^{+}$channel $[7,8]$. Additionally, remodelling of vascular wall causes endothelial and smooth muscle cells (SMC) to become thin and spread around a larger surface, thus decreasing PVR.

Normal pulmonary vascular tone is regulated by complex interactions between vasodilators (prostaglandins, NO) and vasoconstrictors (endothelin-1, thromboxane). NO is an endothelial derived relaxing factor synthesized by oxidation of 1-arginine to 1-citrulline by endothelial NO-synthase (eNOS) enzymes. An increase in pulmonary expression of both eNOS and its downstream target soluble guanylate cyclase (sGC) is seen at term gestation and is critical to the postnatal adaptation as NO is not stored intracellularly [8]. At birth, NO stimulates sGC in vascular SMCs, which converts GTP to cGMP. Increased cGMP levels lead to decreased 
Table 1. Drugs Used for Management of PPHN

\begin{tabular}{|c|c|c|c|}
\hline Therapy & Mechanism of Action & Doses & Side Effects \\
\hline Inhaled NO [46] & $\begin{array}{l}\text { Increased cGMP levels via } \\
\text { stimulation of sGC activity }\end{array}$ & $\begin{array}{l}5-20 \mathrm{ppm} \text { through } \\
\text { ventilator }\end{array}$ & $\begin{array}{l}\text { Methemoglobinemia, formation of } \\
\mathrm{NO}_{2} \text { and peroxinitrite, inhibition of } \\
\text { platelet aggregation }\end{array}$ \\
\hline $\begin{array}{l}\text { Dipyridamole } \\
{[47]}\end{array}$ & $\begin{array}{l}\text { Increased cGMP levels via } \\
\text { non-specific PDE inhibition }\end{array}$ & IV $0.3-0.6 \mathrm{mg} / \mathrm{kg}$ & $\begin{array}{l}\text { Systemic vasodilation and } \\
\text { hypotension }\end{array}$ \\
\hline $\begin{array}{l}\text { Sildenafil }[50, \\
51]\end{array}$ & $\begin{array}{l}\text { Increased cGMP levels via } \\
\text { specific PDE-5 inhibition }\end{array}$ & $\begin{array}{l}\text { PO } 0.5 \text { - } 2 \mathrm{mg} / \mathrm{kg} / \\
\text { dose every } 6 \text { hours IV } \\
0.4 \mathrm{mg} / \mathrm{kg} \text { over } 3 \mathrm{hr} \\
\text { loading f/b infusion } \\
1.6 \mathrm{mg} / \mathrm{kg} / \mathrm{d}\end{array}$ & $\begin{array}{l}\text { Hypotension especially with } \mathrm{NO} \text {, } \\
\text { impaired retinal vascular growth, } \\
\text { thrombocytopenia is a relative } \\
\text { contraindication }\end{array}$ \\
\hline Milrinone [53] & $\begin{array}{l}\text { Increased cAMP levels via } \\
\text { specific PDE-3 inhibition }\end{array}$ & $\begin{array}{l}0.33-0.99 \mu \mathrm{g} / \mathrm{kg} / \mathrm{min} \\
\text { IV infusion }\end{array}$ & $\begin{array}{l}\text { Systemic hypotension, } \\
\text { Intraventricular hemorrhage (IVH) }\end{array}$ \\
\hline $\begin{array}{l}\text { Prostacyclin } \\
\left(\mathrm{PGI}_{2}\right)[54,55]\end{array}$ & $\begin{array}{l}\text { Increased cAMP levels via } \\
\text { adenylate cyclase enzyme }\end{array}$ & $\begin{array}{l}5-40 \mathrm{ng} / \mathrm{kg} / \mathrm{min} \mathrm{IV} \\
\text { infusion }\end{array}$ & Hypotension \\
\hline Iloprost [56] & $\begin{array}{l}\text { Increased cAMP levels via } \\
\text { adenylate cyclase enzyme }\end{array}$ & $\begin{array}{l}20 \mu \mathrm{g} / \mathrm{kg} / \mathrm{dose} \text { every } \\
90 \mathrm{~min} \text { inhalation }\end{array}$ & None reported \\
\hline $\begin{array}{l}\text { Beraprost sodium } \\
{[57]}\end{array}$ & $\begin{array}{l}\text { Increased cAMP levels via } \\
\text { adenylate cyclase enzyme }\end{array}$ & $\begin{array}{l}0.5-1.0 \mu \mathrm{g} / \mathrm{kg} / \mathrm{dose} \\
12 \text { hourly }\end{array}$ & $\begin{array}{l}\text { Watery diarrhoea, flushing, } \\
\text { headache }\end{array}$ \\
\hline $\begin{array}{l}\text { Magnesium } \\
\text { Sulphate [59] }\end{array}$ & $\begin{array}{l}\text { Modulates vascular } \\
\text { contraction by affecting } \\
\text { calcium influx thereby } \\
\text { inhibits SMC depolarization } \\
\text { and promotes vasodilation }\end{array}$ & $\begin{array}{l}\text { IV } 200 \mathrm{mg} / \mathrm{kg} \text { loading } \\
\text { over } 20 \mathrm{~min} \mathrm{f} / \mathrm{b} 20 \text { - } \\
150 \mathrm{mg} / \mathrm{kg} / \mathrm{h} \text { infusion }\end{array}$ & $\begin{array}{l}\text { Bradycardia, hypotension, } \\
\text { respiratory depression }\end{array}$ \\
\hline $\begin{array}{l}\text { Adenosine }[60, \\
61]\end{array}$ & $\begin{array}{l}\text { Release of endogenous } \\
\mathrm{NO} \text {, stimulation of } \mathrm{K}^{+} \text {-ATP } \\
\text { channels, and decreased } \\
\text { calcium influx }\end{array}$ & $\begin{array}{l}30-90 \mu \mathrm{g} / \mathrm{kg} / \mathrm{min} \text { IV } \\
\text { infusion }\end{array}$ & \\
\hline Bosentan $[62,63]$ & $\begin{array}{l}\text { Increased cGMP levels via } \\
\text { ET-1 receptor antagonism }\end{array}$ & $\begin{array}{l}\text { PO } 1 \mathrm{mg} / \mathrm{kg} / \text { dose } 12 \\
\text { hourly }\end{array}$ & Systemic hypotension \\
\hline
\end{tabular}

NO: nitric oxide; SGC: soluble guanylate cyclase; PDE: phosphodiesterase; SMC: smooth muscle cell; cGMP: cyclic guanosine monophosphate; cAMP: cyclic adenosine monophosphate; IV: intravenous; PO: per oral.

$\mathrm{Ca}++$ influx and vasorelaxation. Phosphodiesterase-5 (PDE5) enzyme converts cGMP to inactive 5'GMP limiting the duration of vasodilation. Vascular endothelial growth factor (VEGF), found in bronchial epithelium and SMCs, promotes angiogenesis and vasculogenesis alongwith vasodilation via NO release [9] (Fig. 1).

The natriuretic peptides, atrial (ANP) and brain (BNP), dilate pulmonary arteries by augmenting intracellular cGMP levels via particulate-GC [10]. PG-synthesis is also activated by birth-related stimuli in fetal lungs and mediates pulmonary vasodilation. $\mathrm{PGI}_{2}$ causes vasodilation by converting ATP to cAMP via adenylate cyclase in SMCs thus decreas- ing $\mathrm{Ca}^{++}$influx. This action is limited by inactivation of cAMP by PDE-3 [11]. Endothelin-1, a 21-amino acid polypeptide produced by ECs, has potent vasoactive properties and is mitogenic for pulmonary vessels. Endothelin-1 (ET-1) mediates vasoconstriction via ETA receptors on SMCs while vasodilation via $\mathrm{ET}_{\mathrm{B}}$ receptors on $\mathrm{ECs}$ [12]. Thomboxane is an important vasoconstrictor after birth and in group-B streptococcal infection but does not seem to affect fetal vascular tone. Leukotrienes, in turn, seem to be important for baseline vascular tone of fetal lung. Pulmonary artery SMCs also show independent response to oxygen and hypoxia by means of activation of specific $\mathrm{K}^{+}$-channels [8]. 


\section{Pathophysiologic Changes in PPHN}

Failure of normal postnatal adaptation due to various factors (for example, inadequate oxygenation or lung expansion, failure of $\mathrm{NO}$ or prostaglandin release) results in high PVR and right-to-left shunting of blood, the key pathophysiologic feature of PPHN. Based on the pulmonary vascular morphology, PPHN can be characterised by three anatomic changes: 1). Maladaptation: Abnormal vasoconstriction of structurally normal pulmonary vascular bed induced by hypoxia due to nuchal cord compression, airway obstruction, MAS, RDS, or pneumonia; 2). Pulmonary vascular remodelling: Excessive in-utero muscularization of vascular beds in lungs with normal parenchyma due to intrauterine exposure to drugs or CHDs; 3). Hypoplastic pulmonary vasculature: Intrauterine anomalies ( $\mathrm{CDH}$, oligohydramnios) induced decrease in bronchial branching or decrease in number and size of alveoli resulting in hypoplastic lungs [13].

Understanding the pathophysiology of abnormal vascular remodelling in PPHN is of utmost importance in directing the therapy. Disruption of NO-cGMP, PG-cAMP, and endothelin signalling pathways are important underlying mechanisms of PPHN $[8,14]$. NO-cGMP pathway has shown alterations including decreased availability of arginine, decreased expression of eNOS, decreased sGC activity, decreased NO production and increased PDE-5 activity, in both animal models and neonates with PPHN [15-17]. Animal studies also suggested the role of impaired VEGF signalling in PPHN [9]. Elevated ET-1 levels are seen in PPHN concomitant with decreased eNOS activity and cGMP levels [18].

Caesarean delivery without prior labour seems to be the single greatest risk factor for PPHN, others being obesity, maternal diabetes mellitus and prenatal exposure to aspirin, NSAIDs and SSRIs [19-21]. Prenatal NSAIDs exposure increases the risk of PPHN by inhibiting cyclooxygenase with decreased PG-synthesis and prenatal constriction of ductus arteriosus. SSRIs exposure during late pregnancy increases PPHN risk, by increased 5- $\mathrm{HT}_{2} \mathrm{~A}$ receptor and Rho kinase activation mediated pulmonary vasoconstriction [21].

\section{Diagnosis}

The clinical diagnosis of PPHN should be considered in newborns, especially near or full-term, presenting with hypoxemia refractory to oxygenation and lung recruitment strategies $\left(\mathrm{PaO}_{2}<55\right.$ despite $100 \%$ oxygen $)$. Physical examination may reveal tachypnea, retractions, grunting, cyanosis, prominent S2, and systolic murmur of tricuspid regurgitation; however, these are not diagnostic of PPHN. Chest $\mathrm{X}$-ray can be normal (in primary PPHN) or shows signs of underlying parenchymal lung disease. Higher preductal (right radial artery) $\mathrm{PaO}_{2}(\geq 20 \mathrm{mmHg}$ ) and oxygen saturation ( $\geq 10 \%$ ) compared to postductal (umbilical artery) lo- cation in absence of CHD suggests significant right-to-left shunting and PPHN [8].

Echocardiography with real-time Doppler flow studies continues to be the gold standard to confirm the diagnosis. It help rule out CHD, document right-to-left shunt and estimate PAP from Doppler velocity measurement of tricuspid regurgitation jet [22]. Finally, some cases may require cardiac catheterization to confirm the diagnosis by direct visualization of cardiopulmonary anatomy. During catheterization, pulmonary hypertension is defined as PAP > 25 - $30 \mathrm{mmHg}$ [23]. Response to iNO, if available, can also be used to differentiate PPHN from cyanotic CHD. Elevated BNP level, a biomarker of cardiac ventricular strain, is seen in PPHN but not other respiratory diseases. Monitoring BNP levels can help to evaluate the course of PPHN and to predict rebound after weaning iNO [24].

\section{Management of PPHN}

Basic principle is to avoid hypoxia and to achieve selective pulmonary vasodilation without affecting systemic vascular resistance (SVR) thus reducing PVR:SVR ratio and intracardiac shunting. Early stage of PPHN results from dynamic pulmonary vasospasm, with labile flow through pulmonary circuit while later stages ( $>14$ days) are characterised by increased extracellular matrix deposition and medial SMC proliferation with progressively diminished response to vasodilators [25]. Treatment is directed to improve oxygenation (mechanical ventilation, surfactant replacement), maintain adequate systemic perfusion (fluid replacement, inotropic support), achieve pulmonary vasodilatation by (increasing levels of eNOS substrates namely oxygen and arginine, providing $\mathrm{NO} / \mathrm{PGI}_{2}$ or inhibiting PDE-5 or PDE-3), and to treat underlying diseases (parenchymal lung or systemic disease) (Table 1).

\section{General measures}

Treatment of underlying diseases and metabolic abnormalities

Every effort should be made to find out the underlying disease and to treat it, for example, adequate antibiotic coverage for pneumonia and sepsis. Metabolic abnormalities including hypoglycemia, hypocalcemia, and hypomagnesemia should be corrected to ensure adequate myocardial function and response to vasopressors.

\section{Surfactant therapy}

It improves alveolar expansion and gas exchange in parenchymal diseases, for example, MAS and pneumonia. It has been shown to improve oxygenation and decrease the need for extra-corporeal membrane oxygenation (ECMO) in neo- 
nates with severe respiratory failure [26, 27].

\section{Maintaining systemic perfusion}

Normal systemic perfusion is necessary to ensure optimum tissue oxygenation and to reduce right-to-left shunting. This can be achieved by restoration of intravascular volume with isotonic fluids and/or albumin and vasopressor therapy, for example, dopamine, dobutamine, epinephrine or nor-epinephrine. Recently, norepinephrine has shown to improve lung function in PPHN by decreasing PVR:SVR ratio and improving cardiac functions [28].

\section{Sedation and muscle relaxation}

Environmental stimuli should be minimized as they worsen the clinical situation by increasing PVR through catecholamine release. During mechanical ventilation, sedation with fentanyl (1 - $5 \mu \mathrm{g} / \mathrm{kg} / \mathrm{h}$ infusion) or morphine $(10-15 \mu \mathrm{g} / \mathrm{kg} / \mathrm{h}$ infusion) and muscle relaxation (for example, pancuronium) can be used to facilitate ventilation by minimizing effects of environmental stimulation and pain. However, use of muscle relaxants is controversial due to adverse effects including hypotension, oedema, altered ventilation-perfusion match, and higher mortality and hearing impairment among survivors $[3,29]$. Therefore, their routine use should be avoided or limited for short duration in patients who fail to respond other measures [8].

\section{Alkalosis}

Correction of respiratory and metabolic acidosis has shown to improve pulmonary vasodilation and alkalosis to produce pH $7.50-7.60$ or higher was the most common therapy used before introduction of iNO [3,30]. However, routine use of alkalosis should be avoided as it decreases cerebral perfusion with resultant hearing loss and neurological disabilities among survivors [31].

\section{Oxygenation and mechanical ventilation}

Oxygen is a potent pulmonary vasodilator and neonates with mild respiratory distress can be managed with supplemental oxygen (by nasal cannula or hood) alone or nasal continuous positive airway pressure. However, ventilator support may be required in neonates with moderate respiratory distress having persistent hypoxemia despite supplemental oxygen, or progressing to respiratory failure. It improves ventilationperfusion match by facilitating alveolar recruitment and lung expansion.

\section{Hyperventilation vs. gentle ventilation}

Conventionally, hyperventilation was used to produce hypo- carbia and respiratory alkalosis thus to improve oxygenation by reducing PAP [32]. Ventilator strategy included high respiratory rate (100 - 150/minute) and sufficient PIP to achieve $\mathrm{PaO}_{2}$ upto 80 - $100 \mathrm{mmHg}$, pH 7.50 - 7.60, and $\mathrm{PaCO}_{2}$ as low as $16 \mathrm{mmHg}[32,33]$. However, as hyperventilation and resultant hypocarbia result in poor respiratory and neurologic outcomes, it is no longer recommended therapy except as a potentially life-saving short-term measure [34].

Wung et al proposed gentle ventilation with permissive hypercapnia as an alternative strategy and demonstrated greater survival and lower incidence of bronchopulmonary dysplasia [35]. They used PIP sufficient to produce adequate chest excursion, PEEP $4-5 \mathrm{~cm}-\mathrm{H}_{2} \mathrm{O}$, and rate $40 / \mathrm{min}$ to maintain $\mathrm{PaO} 2$ between $50-70 \mathrm{mmHg}$ and to accept $\mathrm{PaCO}_{2}$ upto $40-60 \mathrm{mmHg}[35,36]$. This approach showed overall improvement in survival, especially for infants with $\mathrm{CDH}$ [36].

\section{High-frequency oscillatory ventilation ( $\mathrm{HFOV}$ )}

HFOV has been advocated to improve lung inflation while potentially decreasing lung injury through volutrauma. HFOV has been used effectively to treat patients with severe respiratory failure, who are being considered for ECMO $[27,37]$. Combined iNO and HFOV therapy was found to be more effective in rescuing infants with severe PPHN, probably by improving intrapulmonary shunt which favours release of NO in the area of action [38].

\section{Inhaled NO therapy}

Inhaled NO is a potent and rapid vasodilator which can be delivered through conventional or high-frequency ventilator directly to airspaces adjacent to pulmonary vessels, from where it rapidly diffuses to vascular SMCs and causes vasodilation by increasing c-GMP levels. Recently, a study has demonstrated feasibility of iNO delivery by oxygen hood [39]. NO is rapidly inactivated by binding to haemoglobin in the blood stream, limiting its systemic effects, iNO is preferentially distributed to the ventilated segments of lungs resulting in increased perfusion and optimized ventilationperfusion match.

Randomized controlled trials (RCT) and Cochrane review (which included 14 prospective RCTs) showed improved oxygenation in $>50 \%$ of newborns and decreased need for ECMO [5, 6, 40-42]. However, upto 30\% cases failed to show adequate response to iNO or to maintain it, especially in $\mathrm{CDH}$ patients. Similarly, they failed to demonstrate improved final outcome including mortality, length of hospitalization, and incidence of chronic lung disease and neurodevelopmental impairment among survivors $[5,6,42$, 43].

Ideal starting dose is $20 \mathrm{ppm}$ with effective doses being 5 - $20 \mathrm{ppm}$. An early response (namely improved oxygenation 
within 60 minutes of starting therapy) is associated with improved outcome, reflects reversibility of pulmonary pathophysiology and may serve as a bedside marker of the disease stage [43]. Ideal initiation timing is still controversial, as earlier studies failed to demonstrate improved outcome including mortality, ECMO need or neurodevelopmental impairments with early iNO but recent studies showed improved oxygenation and decreased probability of developing severe hypoxemic respiratory failure with early use of iNO in newborns with moderate respiratory failure [44, 45].

Weaning from iNO should be aggressively started as soon as patient's condition stabilizes, usually within 24 hours. Sudden discontinuation can precipitate pulmonary vasoconstriction and clinical deterioration, even in non-responders; therefore, iNO should be weaned gradually from $20 \mathrm{ppm}$ to the lowest possible dose (1 ppm) before its discontinuation [46]. Higher doses (>20 ppm) and prolonged iNO use can induce toxicity including lung toxicity due to production of nitrogen dioxide and peroxynitrites, methemoglobinemia (due to oxidation of haemoglobin by NO), and inhibition of platelet aggregation [42].

Presently available evidences support the use of iNO in infants with hypoxic respiratory failure unresponsive to other therapy, excluding $\mathrm{CDH}$ and should be instituted before progression to severe respiratory failure [8].

\section{Phosphodiesterase inhibitors}

Weaning from iNO is sometimes associated with rebound pulmonary hypertension ( $\mathrm{PH}$ ) due to decreased eNOS activity and increased ET-1 level mediated decreased endogenous NO production. Therefore, other mechanisms to enhance cGMP levels are potential areas of research. Mammalian phosphodiesterases, subdivided into 11 families depending upon substrate specificity and sensitivity, are widely distributed in normal tissues with high concentrations in pulmonary vasculature [47]. PDE inhibition increases cAMP and cGMP concentrations locally leading to hyperpolarization of SMCs and vasorelaxation. Non-specific PDE-inhibitors include caffeine, theophylline, dipyridamole, and pentoxifylline. Milrinone and amrinone are specific PDE-3 inhibitors while zaprinast and sildenafil are specific PDE-5 inhibitors [47]. Dipyridamole was used in PPHN to enhance the efficacy of iNO and prevent rebound $\mathrm{PH}$ during weaning but has significant systemic vasodilatory effects. Zaprinast and pentoxifylline have not been adequately studied.

\section{Sildenafil}

Animal and adult studies followed by uncontrolled studies in PPHN showed marked improvement in PVR and survival after sildenafil use. Recent RCTs conducted in resource-limiting settings and Cochrane review showed steady improvement in oxygenation after first dose of oral sildenafil with significant reduction in mortality [48-50]. Similarly, intravenous sildenafil has shown to improve oxygenation without causing systemic hypotension [51]. Although, sildenafil has shown its efficacy both singly as well as in conjunction with iNO to prevent rebound PH and to facilitate it's weaning, further RCTs are required to demonstrate its safety, efficacy, doses and forms of administration.

\section{Milrinone}

Milrinone has been shown to reduce PVR and PAP in animal studies, adults, and post-cardiac surgery neonates. Recent reports showed early and sustained improvement in oxygenation, decrease in rebound $\mathrm{PH}$ after discontinuation of iNO and enhanced pulmonary vasodilation in infants refractory to iNO $[52,53]$. However, contribution of its inodilator effect on myocardial function in PPHN may be substantial. Therefore, whether milrinone as monotherapy may be beneficial warrants further investigation and it should be considered when iNO is unavailable or administration is impractical, for example, during transport.

\section{Other pharmacologic agents}

\section{Prostacyclin, iloprost and beraprost sodium}

Prostacyclin promotes vasodilation and inhibits SMC proliferation via membrane-bound adenylate cyclase mediated increase in cAMP levels. Although, intravenous infusion may be associated with hypotension, inhaled $\mathrm{PGI}_{2}$ have vasodilator effects limited to pulmonary circulation. Effects of $\mathrm{PGI}_{2}$ can be complementary to iNO as they stimulate different cyclic nucleotides and available reports on its use in PPHN demonstrated enhanced oxygenation in newborns refractory to iNO $[54,55]$.

Iloprost, stable $\mathrm{PGI}_{2}$ analogue, can be given by intermittent nebulisation as opposed to continuous nebulisation required with $\mathrm{PGI}_{2}$. Iloprost is recently approved for treatment of pulmonary arterial hypertension in adults. It has also shown to improve oxygenation in neonates with PPHN [56]. Recently, Beraprost sodium, an orally active, stable prostacyclin analogue, has shown significant improvement in oxygenation in infants with PPHN [57].

\section{Magnesium sulphate}

Magnesium, a physiological calcium-antagonist, modulates vasoactivity by decreasing calcium influx and thereby, inhibits SMC depolarization and promotes vasodilatation. $\mathrm{MgSO}_{4}$ may help in PPHN by virtue of its sedative, muscle relaxant and bronchodilator effects, or associated alkalosis. Uncontrolled studies demonstrated improved oxygenation within one hour of $\mathrm{MgSO}_{4}$ infusion, with significantly increase at six hours of therapy [58]. Recent RCT showed better out- 
come of infants treated with iNO after previous exposure to $\mathrm{MgSO}_{4}$, which could be due to combined effect of sustained vasodilator action of $\mathrm{MgSO}_{4}$ and rapid onset of action of iNO [59].

\section{Adenosine}

Adenosine, a purine nucleoside, has pulmonary vasodilator effects mediated via release of endogenous $\mathrm{NO}$, stimulation of $\mathrm{K}^{+}$-ATP channels, and decreased calcium influx. Adenosine infusion improved oxygenation without causing hypotension or tachycardia in neonates with PPHN [60, 61].

\section{Bosentan}

Bosentan, an oral dual $\mathrm{ET}_{\mathrm{A}}$ and $\mathrm{ET}_{\mathrm{B}}$ receptor antagonist, mediates pulmonary vasodilation by blocking effects of endothelin-1. As significantly improved oxygenation has been seen after bosentan use without significant adverse effects, it may be used as adjuvant therapy in PPHN, especially in resource-limited countries $[62,63]$.

\section{ECMO}

ECMO is a life-saving rescue therapy to support neonates with severe respiratory failure, who failed to respond to conventional therapies including iNO. ECMO is an invasive method of partial cardio-pulmonary bypass to provide respiratory and cardiac support and thus, facilitates postnatal adaptation, decreases barotrauma and oxygen toxicity and promotes lung recovery. ECMO has significantly improved survival of neonates with severe but reversible lung disease without increased risk of severe disability [14, 64, 65]. ECMO as an option is almost nonexistent in developing countries and even in developed countries; availability is limited to few specialist centres only. Newer therapies including iNO, HFO, and surfactant have significant reduced the need for ECMO in PPHN and it is now mostly limited to iNO non-responders especially $\mathrm{CDH}$ with pulmonary hypoplasia [27].

\section{New Insights Into Pathophysiology and Man- agement of PPHN}

\section{Role of oxidant stress}

Increasing evidences suggested the role of reactive oxygen species (ROS), for example, superoxide, hydrogen peroxide $\left(\mathrm{H}_{2} \mathrm{O}_{2}\right)$, and peroxinitrite in pulmonary vasoconstriction and vascular remodelling in PPHN. Superoxide is an oxygen free radical generated in pulmonary arteries by xanthine oxidase, NADPH-oxidase, or uncoupled eNOS in ECs [66]. Although, mechanism of ROS induction is not well-known, endothelin and angiotensin are found to activate NADPHoxidase in vascular SMCs [66-68]. Decreased availability of arginine, tetrahydrobiopterin, and heat shock protein-90, lead to uncoupling of eNOS and release of superoxide [68].

\section{Free radical scavengers and other investigational agents}

ROS scavenger superoxide dismutase (SOD) converts superoxide radical to $\mathrm{H}_{2} \mathrm{O}_{2}$, which is subsequently converted to water by catalase. Studies have demonstrated that recombinant human SOD (rhSOD) augments PDE-5 expression, vasodilatory response to iNO and oxygenation in PPHN lamb models $[69,70]$. Furthermore, rhSOD treatment appeared to block formation of oxidants like peroxynitrite and isoprostanes.

Other agents which have shown promising results in laboratory studies by decreasing PVR and promoting vasodilation by various mechanisms include BAY 41-2272 (a novel GC activator), Fasudil (a Rho-kinase inhibitor), intrapulmonary recombinant human VEGF infusion (by upregulating eNOS), and intrapulmonary catalase administration (by decreasing ROS mediated vascular remodelling), high-dose hydrocortisone (by decreasing PDE5 and ROS activity, and increasing cGMP levels, sGC and SOD activity), apocynin (NADPH oxidase inhibitor improve oxygenation by attenuating ROS-mediated vasoconstriction and by increasing NOS activity, increased tetrahydrobiopterin (an eNOS co-factor) levels via sepiapterin supplementation (improves NO production by improving eNOS function and restoring angiogenesis), and antenatal betamethasone (improves response to pulmonary vasodilators by reversing increased superoxide/ decreased cGMP levels and restoring Hsp90-eNOS interactions) [71-78]. Thus, an antioxidant therapeutic approach may have multiple beneficial effects such as increased availability of endogenous and exogenous NO, reduced oxidative stress and reduced lung injury. Hopefully, human trials will begin soon.

\section{Future Perspectives}

Future studies are required to give new insight into pathophysiology of PPHN and to develop new strategies for its management. Studies are required to determine ideal initiation time, minimal effective dose, safety and length of iNO therapy in both term and preterm newborns. Studies are undergoing to determine whether non-invasive delivery of iNO via CPAP or nasal cannula will provide additional advantages. In future, amplification of eNOS activity may become possible, or newer NO-donor drugs, for example, $S$-nitrosothiols, may emerge as superior vehicles to deliver NO to specific tissue beds. Another exciting avenue for future research is neuroprotective effects of iNO, especially in preterm infants.

Trials are undergoing to determine the safety, efficacy, 
and long-term outcome of other treatment modalities, for example, surfactant, HFO, and other pulmonary vasodilators including PDE-inhibitors, oral and inhaled prostacyclin analogues, and ET-1 antagonists either as a sole therapy or alongwith iNO [79-82]. Finally, as recent laboratory studies have demonstrated the role of oxidant stress in PPHN, future research will better define the enzymatic and cellular sources of oxidants, role of endogenous antioxidant systems, and benefits of anti-oxidant therapies.

\section{Conclusion}

PPHN remains a significant cause of perinatal morbidity and mortality. Assisted ventilation and pharmacologic manipulation are the mainstays of treatment. Presently, iNO is the only FDA-approved selective pulmonary vasodilator for infant with hypoxemic respiratory failure/PPHN. ECMO, if available, should be considered for infants with good neurologic potential who fail to respond to the conventional modalities. As these modalities are available in few selected centres only, other alternatives especially PDE-inhibitors (sildenafil and milrinone), and magnesium sulphate have made a definite space in neonatologists, armamentarium to battle with PPHN in resource-limited settings. Still, any single agent can not be labelled as a magic bullet for PPHN and as the number of therapies grows, it is important to target therapies to the underlying pathophysiology. Further research in this field will ensure that new therapies are based on evidence in order to improve outcome of neonates with PPHN.

\section{Acknowledgement}

Nil.

\section{Funding}

Nil.

\section{Conflict of Interested}

None.

\section{Authorship Contributions}

RA: Acquisition of data, drafting the article, and literature review; AA: Concept, manuscript review, manuscript editing, revising the article critically for important intellectual content; AA will act as guarantor. Both the authors approved the final manuscript.

\section{Abbreviations}

NSAIDs: non-steroidal anti-inflammatory agents; SSRIs: selective serotonin reuptake inhibitors; ATP: adenine triphosphate; GTP: guanine triphosphate; c-AMP: cyclic adenosine mono phosphate; c-GMP: cyclic guanosine mono phosphate; PIP: peak inspiratory pressure; PEEP: peak end expiratory pressure

\section{References}

1. Gersony WM, Duc GV, Sinclair JC. "PFC Syndrome" (Persistence of fetal circulation). Circulation 1969;40:87.

2. Lakshminrusimha S, Steinhorn RH. Pulmonary vascular biology during neonatal transition. Clin Perinatol. 1999;26(3):601-619.

3. Walsh-Sukys MC, Tyson JE, Wright LL, Bauer CR, Korones SB, Stevenson DK, Verter J, et al. Persistent pulmonary hypertension of the newborn in the era before nitric oxide: practice variation and outcomes. Pediatrics. 2000;105(1 Pt 1):14-20.

4. Yoder BA, Kirsch EA, Barth WH, Gordon MC. Changing obstetric practices associated with decreasing incidence of meconium aspiration syndrome. Obstet Gynecol. 2002;99(5 Pt 1):731-739.

5. Inhaled nitric oxide in full-term and nearly full-term infants with hypoxic respiratory failure. The Neonatal Inhaled Nitric Oxide Study Group. N Engl J Med. 1997;336(9):597-604.

6. Konduri GG, Solimano A, Sokol GM, Singer J, Ehrenkranz RA, Singhal N, Wright LL, et al. A randomized trial of early versus standard inhaled nitric oxide therapy in term and near-term newborn infants with hypoxic respiratory failure. Pediatrics. 2004;113(3 Pt 1):559-564.

7. Abman SH, Chatfield BA, Hall SL, McMurtry IF. Role of endothelium-derived relaxing factor during transition of pulmonary circulation at birth. Am J Physiol. 1990;259(6 Pt 2):H1921-1927.

8. Konduri GG, Kim UO. Advances in the diagnosis and management of persistent pulmonary hypertension of the newborn. Pediatr Clin North Am. 2009;56(3):579600 , Table of Contents.

9. Abman SH. Impaired vascular endothelial growth factor signaling in the pathogenesis of neonatal pulmonary vascular disease. Adv Exp Med Biol. 2010;661:323-335.

10. Matsushita T, Hislop AA, Boels PJ, Deutsch J, Haworth SG. Changes in ANP responsiveness of normal and hypertensive porcine intrapulmonary arteries during maturation. Pediatr Res. 1999;46(4):411-418.

11. Leffler CW, Hessler JR, Green RS. The onset of breathing at birth stimulates pulmonary vascular prostacyclin synthesis. Pediatr Res. 1984;18(10):938-942.

12. Galie N, Manes A, Branzi A. The endothelin system 
in pulmonary arterial hypertension. Cardiovasc Res. 2004;61(2):227-237.

13. Geggel RL, Reid LM. The structural basis of PPHN. Clin Perinatol. 1984;11(3):525-549.

14. Farrow KN, Fliman P, Steinhorn RH. The diseases treated with ECMO: focus on PPHN. Semin Perinatol. 2005;29(1):8-14.

15. Villanueva ME, Zaher FM, Svinarich DM, Konduri GG. Decreased gene expression of endothelial nitric oxide synthase in newborns with persistent pulmonary hypertension. Pediatr Res. 1998;44(3):338-343.

16. Tzao C, Nickerson PA, Russell JA, Gugino SF, Steinhorn RH. Pulmonary hypertension alters soluble guanylate cyclase activity and expression in pulmonary arteries isolated from fetal lambs. Pediatr Pulmonol. 2001;31(2):97-105.

17. Pearson DL, Dawling S, Walsh WF, Haines JL, Christman BW, Bazyk A, Scott N, et al. Neonatal pulmonary hypertension--urea-cycle intermediates, nitric oxide production, and carbamoyl-phosphate synthetase function. N Engl J Med. 2001;344(24):1832-1838.

18. Kumar P, Kazzi NJ, Shankaran S. Plasma immunoreactive endothelin- 1 concentrations in infants with persistent pulmonary hypertension of the newborn. Am J Perinatol. 1996;13(6):335-341.

19. Delaney C, Cornfield DN. Risk factors for persistent pulmonary hypertension of the newborn. Pulm Circ. 2012;2(1):15-20.

20. Wilson KL, Zelig CM, Harvey JP, Cunningham BS, Dolinsky BM, Napolitano PG. Persistent pulmonary hypertension of the newborn is associated with mode of delivery and not with maternal use of selective serotonin reuptake inhibitors. Am J Perinatol. 2011;28(1):19-24.

21. t Jong GW, Einarson T, Koren G, Einarson A. Antidepressant use in pregnancy and persistent pulmonary hypertension of the newborn (PPHN): a systematic review. Reprod Toxicol. 2012;34(3):293-297.

22. Peterson AL, Deatsman S, Frommelt MA, Mussatto K, Frommelt PC. Correlation of echocardiographic markers and therapy in persistent pulmonary hypertension of the newborn. Pediatr Cardiol. 2009;30(2):160-165.

23. Adatia I. Recent advances in pulmonary vascular disease. Curr Opin Pediatr. 2002;14(3):292-297.

24. Vijlbrief DC, Benders MJ, Kemperman H, van Bel F, de Vries WB. B-type natriuretic peptide and rebound during treatment for persistent pulmonary hypertension. $\mathrm{J}$ Pediatr. 2012;160(1):111-115 e111.

25. Fike CD, Kaplowitz MR. Effect of chronic hypoxia on pulmonary vascular pressures in isolated lungs of newborn pigs. J Appl Physiol. 1994;77(6):2853-2862.

26. Engle WA. Surfactant-replacement therapy for respiratory distress in the preterm and term neonate. Pediatrics. 2008;121(2):419-432.

27. Fliman PJ, deRegnier RA, Kinsella JP, Reynolds M,
Rankin LL, Steinhorn RH. Neonatal extracorporeal life support: impact of new therapies on survival. J Pediatr. 2006;148(5):595-599.

28. Tourneux P, Rakza T, Bouissou A, Krim G, Storme L. Pulmonary circulatory effects of norepinephrine in newborn infants with persistent pulmonary hypertension. J Pediatr. 2008;153(3):345-349.

29. Cheung PY, Tyebkhan JM, Peliowski A, Ainsworth W, Robertson CM. Prolonged use of pancuronium bromide and sensorineural hearing loss in childhood survivors of congenital diaphragmatic hernia. J Pediatr. 1999;135(2 Pt 1):233-239.

30. Schreiber MD, Heymann MA, Soifer SJ. Increased arterial $\mathrm{pH}$, not decreased $\mathrm{PaCO}$, attenuates hypoxiainduced pulmonary vasoconstriction in newborn lambs. Pediatr Res. 1986;20(2):113-117.

31. Marron MJ, Crisafi MA, Driscoll JM, Jr., Wung JT, Driscoll YT, Fay TH, James LS. Hearing and neurodevelopmental outcome in survivors of persistent pulmonary hypertension of the newborn. Pediatrics. 1992;90(3):392-396.

32. Drummond WH, Gregory GA, Heymann MA, Phibbs RA. The independent effects of hyperventilation, tolazoline, and dopamine on infants with persistent pulmonary hypertension. J Pediatr. 1981;98(4):603-611.

33. Fox WW, Duara S. Persistent pulmonary hypertension in the neonate: diagnosis and management. J Pediatr. 1983;103(4):505-514.

34. Bifano EM, Pfannenstiel A. Duration of hyperventilation and outcome in infants with persistent pulmonary hypertension. Pediatrics. 1988;81(5):657-661.

35. Wung JT, James LS, Kilchevsky E, James E. Management of infants with severe respiratory failure and persistence of the fetal circulation, without hyperventilation. Pediatrics. 1985;76(4):488-494.

36. Gupta A, Rastogi S, Sahni R, Bhutada A, Bateman D, Rastogi D, Smerling A, et al. Inhaled nitric oxide and gentle ventilation in the treatment of pulmonary hypertension of the newborn--a single-center, 5-year experience. J Perinatol. 2002;22(6):435-441.

37. Vitali SH, Arnold JH. Bench-to-bedside review: Ventilator strategies to reduce lung injury -- lessons from pediatric and neonatal intensive care. Crit Care. 2005;9(2):177-183.

38. Kinsella JP, Truog WE, Walsh WF, Goldberg RN, Bancalari E, Mayock DE, Redding GJ, et al. Randomized, multicenter trial of inhaled nitric oxide and high-frequency oscillatory ventilation in severe, persistent pulmonary hypertension of the newborn. J Pediatr. 1997;131(1 Pt 1):55-62.

39. Ambalavanan N, El-Ferzli GT, Roane C, Johnson R, Carlo WA. Nitric oxide administration using an oxygen hood: a pilot trial. PLoS One. 2009;4(2):e4312.

40. Davidson D, Barefield ES, Kattwinkel J, Dudell G, Dam- 
ask M, Straube R, Rhines J, et al. Inhaled nitric oxide for the early treatment of persistent pulmonary hypertension of the term newborn: a randomized, double-masked, placebo-controlled, dose-response, multicenter study. The I-NO/PPHN Study Group. Pediatrics. 1998;101(3 Pt 1):325-334.

41. Goldman AP, Tasker RC, Hosiasson S, Henrichsen T, Macrae DJ. Early response to inhaled nitric oxide and its relationship to outcome in children with severe hypoxemic respiratory failure. Chest. 1997;112(3):752-758.

42. Finer NN, Barrington KJ. Nitric oxide for respiratory failure in infants born at or near term. Cochrane Database Syst Rev. 20064):CD000399.

43. Konduri GG, Vohr B, Robertson C, Sokol GM, Solimano A, Singer J, Ehrenkranz RA, et al. Early inhaled nitric oxide therapy for term and near-term newborn infants with hypoxic respiratory failure: neurodevelopmental follow-up. J Pediatr. 2007;150(3):235-240, 240 e231.

44. Gonzalez A, Fabres J, D’Apremont I, Urcelay G, Avaca M, Gandolfi C, Kattan J. Randomized controlled trial of early compared with delayed use of inhaled nitric oxide in newborns with a moderate respiratory failure and pulmonary hypertension. J Perinatol. 2010;30(6):420424.

45. Wang YF, Liu CQ, Gao XR, Yang CY, Shan RB, Zhuang DY, Chen DM, et al. Effects of inhaled nitric oxide in neonatal hypoxemic respiratory failure from a multicenter controlled trial. Chin Med J (Engl). 2011;124(8):11561163.

46. Davidson D, Barefield ES, Kattwinkel J, Dudell G, Damask M, Straube R, Rhines J, et al. Safety of withdrawing inhaled nitric oxide therapy in persistent pulmonary hypertension of the newborn. Pediatrics. 1999;104(2 Pt 1):231-236.

47. Travadi JN, Patole SK. Phosphodiesterase inhibitors for persistent pulmonary hypertension of the newborn: a review. Pediatr Pulmonol. 2003;36(6):529-535.

48. Vargas-Origel A, Gomez-Rodriguez G, Aldana-Valenzuela C, Vela-Huerta MM, Alarcon-Santos SB, Amador-Licona N. The use of sildenafil in persistent pulmonary hypertension of the newborn. Am J Perinatol. 2010;27(3):225-230.

49. Uslu S, Kumtepe S, Bulbul A, Comert S, Bolat F, Nuhoglu A. A comparison of magnesium sulphate and sildenafil in the treatment of the newborns with persistent pulmonary hypertension: a randomized controlled trial. J Trop Pediatr. 2011;57(4):245-250.

50. Shah PS, Ohlsson A. Sildenafil for pulmonary hypertension in neonates. Cochrane Database Syst Rev. 20118):CD005494.

51. Steinhorn RH, Kinsella JP, Pierce C, Butrous G, Dilleen M, Oakes M, Wessel DL. Intravenous sildenafil in the treatment of neonates with persistent pulmonary hypertension. J Pediatr. 2009;155(6):841-847 e841.
52. Santhosh KT, Elkhateeb O, Nolette N, Outbih O, Halayko AJ, Dakshinamurti S. Milrinone attenuates thromboxane receptor-mediated hyperresponsiveness in hypoxic pulmonary arterial myocytes. Br J Pharmacol. 2011;163(6):1223-1236.

53. McNamara PJ, Laique F, Muang-In S, Whyte HE. Milrinone improves oxygenation in neonates with severe persistent pulmonary hypertension of the newborn. J Crit Care. 2006;21(2):217-222.

54. Golzand E, Bar-Oz B, Arad I. Intravenous prostacyclin in the treatment of persistent pulmonary hypertension of the newborn refractory to inhaled nitric oxide. Isr Med Assoc J. 2005;7(6):408-409.

55. Kelly LK, Porta NF, Goodman DM, Carroll CL, Steinhorn RH. Inhaled prostacyclin for term infants with persistent pulmonary hypertension refractory to inhaled nitric oxide. J Pediatr. 2002;141(6):830-832.

56. Concheiro Guisan A, Sousa Rouco C, Suarez Traba B, Paradela Carreira A, Ocampo Cardalda S, Antelo Cortizas J. [Inhaled iloprost: a therapeutic alternative for persistent pulmonary hypertension of the newborn]. An Pediatr (Barc). 2005;63(2):175-176.

57. Nakwan N, Wannaro J. Persistent pulmonary hypertension of the newborn successfully treated with beraprost sodium: a retrospective chart review. Neonatology. 2011;99(1):32-37.

58. Chandran S, Haqueb ME, Wickramasinghe HT, Wint Z. Use of magnesium sulphate in severe persistent pulmonary hypertension of the newborn. J Trop Pediatr. 2004;50(4):219-223.

59. Boo NY, Rohana J, Yong SC, Bilkis AZ, Yong-Junina F. Inhaled nitric oxide and intravenous magnesium sulphate for the treatment of persistent pulmonary hypertension of the newborn. Singapore Med J. 2010;51(2):144-150.

60. Konduri GG, Garcia DC, Kazzi NJ, Shankaran S. Adenosine infusion improves oxygenation in term infants with respiratory failure. Pediatrics. 1996;97(3):295-300.

61. Ng C, Franklin O, Vaidya M, Pierce C, Petros A. Adenosine infusion for the management of persistent pulmonary hypertension of the newborn. Pediatr Crit Care Med. 2004;5(1):10-13.

62. Mohamed WA, Ismail M. A randomized, double-blind, placebo-controlled, prospective study of bosentan for the treatment of persistent pulmonary hypertension of the newborn. J Perinatol. 2012;32(8):608-613.

63. Radicioni M, Bruni A, Camerini P. Combination therapy for life-threatening pulmonary hypertension in a premature infant: first report on bosentan use. Eur J Pediatr. 2011;170(8):1075-1078.

64. UK collaborative randomised trial of neonatal extracorporeal membrane oxygenation. UK Collaborative ECMO Trail Group. Lancet. 1996;348(9020):75-82.

65. Mugford M, Elbourne D, Field D. Extracorporeal membrane oxygenation for severe respiratory fail- 
ure in newborn infants. Cochrane Database Syst Rev. 20083):CD001340.

66. Brennan LA, Steinhorn RH, Wedgwood S, Mata-Greenwood E, Roark EA, Russell JA, Black SM. Increased superoxide generation is associated with pulmonary hypertension in fetal lambs: a role for NADPH oxidase. Circ Res. 2003;92(6):683-691.

67. Wedgwood S, Steinhorn RH, Bunderson M, Wilham J, Lakshminrusimha S, Brennan LA, Black SM. Increased hydrogen peroxide downregulates soluble guanylate cyclase in the lungs of lambs with persistent pulmonary hypertension of the newborn. Am J Physiol Lung Cell Mol Physiol. 2005;289(4):L660-666.

68. Konduri GG, Ou J, Shi Y, Pritchard KA, Jr. Decreased association of HSP90 impairs endothelial nitric oxide synthase in fetal lambs with persistent pulmonary hypertension. Am J Physiol Heart Circ Physiol. 2003;285(1):H204-211.

69. Lakshminrusimha S, Russell JA, Wedgwood S, Gugino SF, Kazzaz JA, Davis JM, Steinhorn RH. Superoxide dismutase improves oxygenation and reduces oxidation in neonatal pulmonary hypertension. Am J Respir Crit Care Med. 2006;174(12):1370-1377.

70. Farrow KN, Lakshminrusimha S, Czech L, Groh BS, Gugino SF, Davis JM, Russell JA, et al. SOD and inhaled nitric oxide normalize phosphodiesterase 5 expression and activity in neonatal lambs with persistent pulmonary hypertension. Am J Physiol Lung Cell Mol Physiol. 2010;299(1):L109-116.

71. Deruelle P, Grover TR, Abman SH. Pulmonary vascular effects of nitric oxide-cGMP augmentation in a model of chronic pulmonary hypertension in fetal and neonatal sheep. Am J Physiol Lung Cell Mol Physiol. 2005;289(5):L798-806.

72. Tourneux P, Chester M, Grover T, Abman SH. Fasudil inhibits the myogenic response in the fetal pulmonary circulation. Am J Physiol Heart Circ Physiol. 2008;295(4):H1505-1513.

73. Grover TR, Parker TA, Markham NE, Abman SH. rhVEGF treatment preserves pulmonary vascular reactivity and structure in an experimental model of pulmonary hypertension in fetal sheep. Am J Physiol Lung Cell Mol Physiol. 2005;289(2):L315-321.

74. Wedgwood S, Lakshminrusimha S, Fukai T, Russell JA, Schumacker PT, Steinhorn RH. Hydrogen peroxide regulates extracellular superoxide dismutase activity and expression in neonatal pulmonary hypertension. Antioxid Redox Signal. 2011;15(6):1497-1506.

75. Perez M, Lakshminrusimha S, Wedgwood S, Czech L, Gugino SF, Russell JA, Farrow KN, et al. Hydro- cortisone normalizes oxygenation and cGMP regulation in lambs with persistent pulmonary hypertension of the newborn. Am J Physiol Lung Cell Mol Physiol. 2012;302(6):L595-603.

76. Wedgwood S, Lakshminrusimha S, Farrow KN, Czech L, Gugino SF, Soares F, Russell JA, et al. Apocynin improves oxygenation and increases eNOS in persistent pulmonary hypertension of the newborn. Am J Physiol Lung Cell Mol Physiol. 2012;302(6):L616-626.

77. Teng RJ, Du J, Xu H, Bakhutashvili I, Eis A, Shi Y, Pritchard KA, Jr., et al. Sepiapterin improves angiogenesis of pulmonary artery endothelial cells with in utero pulmonary hypertension by recoupling endothelial nitric oxide synthase. Am J Physiol Lung Cell Mol Physiol. 2011;301(3):L334-345.

78. Chandrasekar I, Eis A, Konduri GG. Betamethasone attenuates oxidant stress in endothelial cells from fetal lambs with persistent pulmonary hypertension. Pediatr Res. 2008;63(1):67-72.

79. Actelion. Multicenter, double-blind, placebo-controlled, randomized, prospective study of bosentan as adjunctive therapy to inhaled nitric oxide in the management of Persistent Pulmonary Hypertension of the Newborn (PPHN). In: ClinicalTrials.gov [Internet]. Bethesda (MD): National Library of Medicine (US). 2000- [cited 2012 Jul 11]. Available from: http://clinicaltrial.gov/ show/NCT01389856 NLM Identifier: NCT01389856.

80. Pfizer. Individual matched control open label single arm single centre study to investigate safety and efficacy of sildenafil in near term and term newborns with Persistent Pulmonary Hypertension of the Newborn (PPHN). In: ClinicalTrials.gov [Internet]. Bethesda (MD): National Library of Medicine (US). 2000- [cited 2012 Jul 11]. Available from: http://clinicaltrial.gov/show/ NCT01069861 NLM Identifier: NCT01069861.

81. Salama H, Hamad Medical Corporation. Early combined use of inhaled nitric oxide and oral sildenafil on the outcome of pulmonary hypertension in newborn infants. In: ClinicalTrials.gov [Internet]. Bethesda (MD): National Library of Medicine (US). 2000- [cited 2012 Jul 11]. Available from: http://clinicaltrial.gov/show/ NCT01558466 NLM Identifier: NCT01558466.

82. Kirpalani H, Children's Hospital of Philadelphia. Milrinone pharmacokinetics and pharmacodynamics in newborns with Persistent Pulmonary Hypertension of the Newborn - a pilot study to enable a randomized trial of intervention. In: ClinicalTrials.gov [Internet]. Bethesda (MD): National Library of Medicine (US). 2000- [cited 2012 Jul 11]. Available from: http://clinicaltrial.gov/ show/NCT01088997 NLM Identifier: NCT01088997. 